\title{
A Study of Factors Dissuading the Farmers to Include Chickpea in their Cropping System
}

\author{
Nidhi Sharma ${ }^{1 *}$ Aditya $^{2}$ and P.S. Shehrawat ${ }^{3}$ \\ ${ }^{1}$ Department of Extension Education, Hisar - 125004, Haryana, India \\ ${ }^{2}$ COA, CCS HAU, Hisar - 125004, Haryana, India \\ ${ }^{3}$ CCS Haryana Agricultural University, Hisar - 125004, Haryana, India \\ *Corresponding author
}

\section{A B S T R A C T}

\begin{tabular}{|c|}
\hline $\begin{array}{l}\text { K e y w o r d s } \\
\text { Chickpea cultivation, } \\
\begin{array}{l}\text { Cropping system and } \\
\text { dissuading factors }\end{array} \\
\end{array}$ \\
\hline Article Info \\
\hline $\begin{array}{l}\text { Accepted: } \\
\text { 16 April } 2018 \\
\text { Available Online: } \\
10 \text { May } 2018\end{array}$ \\
\hline
\end{tabular}

The study was conducted in the Bhiwani district of Haryana state to study the major factors, which dissuade the farmers to include chickpea in their cropping system. In this study, two blocks Tosham and Siwani were selected randomly from Bhiwani district and from each block; two villages were selected, randomly. Thus, total four villages, namely (Khanak, Kirawar from Tosham block and Gaindawas and Barwa from Siwani block) were selected, randomly. Further, thirty farmers from each village were selected and thus, total number of 120 farmers was interviewed for the study. The study reported various dissuading factors for not including chickpea in cropping system and it was found that $100 \%$ of the farmers considered "low yield potential of chickpea" was most accountable dissuading factor followed by "lack of promising varieties particularly for irrigated and drought prone areas", "economic losses under storage conditions due to stored grain pests", "high incidence of wilt and root rot" and "poor extent of knowledge about seed treatment" with $99.33 \%, 98.66 \%, 98.33 \%$ and $98 \%$, respectively.

\section{Introduction}

Chickpea is commonly known as gram, which is one of the important pulse crops of the India. About $65 \%$ of global area with $68 \%$ of global production of chickpea is contributed by India.

However, chickpea production in India is slow in post green revolution years due to strong competition from wheat, rice and mustard, as expansion in irrigation and rapid technological change has favored the latter crops at the cost of chickpea. The recent liberalization has expanded the demand for chickpea from international markets in addition to the growing domestic demand. It was observed that the productivity of chickpea was found low in comparison to their potential yield in existing area and it implies improvement in chickpea production is needed through conservation, diversification of agriculture and to enhance adoption level of improved chickpea production technology. Therefore, to increase the productivity, particularly under rain fed chickpea growing regions is one of the major challenges and concern which need to be addressed on priority basis. Many 
researchers had addressed some constraints namely, 'non availability of good High yielding variety (HYV) seeds of pulses', 'lack of knowledge about HYVs', 'poor technical guidance and untimely availability of inputs (agro-chemical, fertilizers, etc.).

Other constraints like 'poor seed storage facilities', 'poor marketing facilities', 'poor transportation for marketing etc.' were socioeconomic infrastructural constraints in pulses production. Farmers encountered 'lack sufficient capital to purchase critical inputs such as seed, fertilizers, and pesticides' also. It was also realised that public extension system is weak to effectively deliver the technology, inputs, and information to the farmers.

On the other hand, grazing of crops by stray animals of the thinly distributed crop is a major limitation to cultivation of pulses. Likewise low volume of produce and lack of markets may deprive the small and marginal producers to get the market prices. By considering all these facts, the present study was proposed to find out factors, which dissuade the farmers to include chickpea in cropping system.

\section{Materials and Methods}

The present study was conducted in Bhiwani district. Two blocks Tosham and Siwani were selected randomly and from each block, two villages were selected randomly, total number of four villages was selected for sampling namely Khanak, Kirawar from Tosham block and Gaindawas and Barwa from Siwani block.

A dissuading factor is defined as a force that restricts the farmers not to adopt the chickpea in cropping system of Rabi season. These dissuading factors pertain to technical, administrative, and farmers 'personal. An inventory of dissuading factors was prepared and all selected farmers were asked to give their responses against each factor, whether it was 'very accountable', 'accountable' and 'not accountable'. Weightage were given to their corresponding responses category were 3,2 , and 1, respectively and an aggregate total score was calculated for all dissuading factors separately.

Based on calculated score; a weighted mean score for each constraint was obtained and it was converted into percentage Ranks were given based on percentage/obtained mean scores for assessing the accountability of factors. The maximum mean score /percentage so obtained were given the rank $1^{\text {st }}$ and the next subsequent one was given $2^{\text {nd }}$ and so on the descending orders. Karl Pearson's correlation coefficient was used to find out the nature of relationship between independent and dependent variables.

\section{Pearson's coefficient of correlation}

This technique was used to find out the relationship between two variables. The formula used was as follows:

$$
r=\frac{N \sum x y-\sum x \sum y}{\left(N \sum x\right)^{2}-\left(\sum x\right)^{2} \cdot\left(N \sum y\right)^{2}-\left(\sum y\right)^{2}}
$$

Where,

$\mathrm{r}=$ Correlation coefficient

$\mathrm{x}=$ Score of independent variable

$\mathrm{y}=$ Score of dependent variable

$\mathrm{N}=$ Number of observation

\section{Results and Discussion}

The data in table 1 indicated that 'low yield potential of chick pea' is very accountable dissuading factor among chickpea growers at $1^{\text {st }}$ rank with 100.00 per cent followed by 'lack of promising varieties particularly for irrigated and drought prone areas'. 
Table.1 Factors, which dissuaded farmers for not including chickpea in cropping system

\begin{tabular}{|c|c|c|c|c|c|c|c|c|}
\hline $\begin{array}{l}\text { Sr. } \\
\text { No. }\end{array}$ & $\begin{array}{l}\text { Dissuading } \\
\text { Factors }\end{array}$ & $\mathbf{V A}(3)$ & $\mathbf{A}(2)$ & $\mathbf{N A}(1)$ & $\begin{array}{l}\text { Total } \\
\text { score }\end{array}$ & $\begin{array}{c}\text { Weighted } \\
\text { Mean } \\
\text { Score }\end{array}$ & $\%$ age & $\begin{array}{l}\text { Rank } \\
\text { order }\end{array}$ \\
\hline 1. & Low yield potential of chick pea & $120(360)$ & $0(0)$ & $0(0)$ & 360 & 3.00 & 100.00 & I \\
\hline 2. & Cannot grow in heavy soil/saline soil & $0(0)$ & $6(12)$ & 114(114) & 126 & 1.05 & 35.00 & XXII \\
\hline 3. & Unstable production levels due to biotic and abiotic stresses & 113(339) & $5(10)$ & $2(2)$ & 351 & 2.92 & 97.33 & VII \\
\hline 4. & Chick pea is sensitive to changing weather conditions & $108(324)$ & $7(14)$ & $5(5)$ & 343 & 2.85 & 95.00 & IX \\
\hline 5. & High cost of seed at the time of sowing & $40(40)$ & $35(70)$ & $45(45)$ & 155 & 1.29 & 43.00 & XXI \\
\hline 6. & Less awareness of the new varieties of chickpea & $101(303)$ & $12(24)$ & $7(7)$ & 334 & 2.78 & 92.66 & XI \\
\hline 7. & Lack of promising varieties & $118(354)$ & $2(4)$ & $0(0)$ & 358 & 2.98 & 99.33 & II \\
\hline 8. & Bio-fertilizers are very costly & $81(255)$ & $17(34)$ & $22(22)$ & 311 & 2.59 & 86.33 & XIV \\
\hline 9. & $\begin{array}{l}\text { Lack of inputs like seed, fertilizers and pesticides for raising } \\
\text { gram }\end{array}$ & 24(72) & 18(36) & 78(78) & 186 & 1.55 & 51.66 & XIX \\
\hline 10. & Low yield in tube well irrigated area & $31(93)$ & 2(4) & $87(87)$ & 184 & 1.53 & 51.00 & $\mathrm{XX}$ \\
\hline 11. & Sensitive to high rainfall & $85(255)$ & $10(20)$ & $25(25)$ & 300 & 2.50 & 83.33 & $\mathrm{XV}$ \\
\hline 12. & Low response to higher application of farm inputs & $30(90)$ & $34(68)$ & $56(56)$ & 214 & 1.78 & 59.33 & XVIII \\
\hline 13. & Heavy weed infestation & $96(288)$ & 2(4) & $22(22)$ & 314 & 2.61 & 87.00 & XIII \\
\hline 14. & Heavy infestation of Helicoverpa armigera & $110(330)$ & $6(12)$ & $4(4)$ & 346 & 2.88 & 96.00 & VIII \\
\hline 15. & High incidence of wilt and root rot & $115(345)$ & $5(10)$ & $0(0)$ & 355 & 2.95 & 98.33 & IV \\
\hline 16. & Heavy infestation of termites & $105(315)$ & $7(14)$ & $8(8)$ & 337 & 2.80 & 93.33 & $\mathrm{X}$ \\
\hline 17. & Viral infestation in desi chana & $100(300)$ & $11(22)$ & $9(9)$ & 331 & 2.75 & 91.66 & XII \\
\hline 18. & Lack of infrastructural facilities for storage & $36(108)$ & $66(132)$ & $18(18)$ & 258 & 2.15 & 71.66 & XVII \\
\hline 19. & $\begin{array}{l}\text { Economic losses under storage conditions due to stored } \\
\text { grain pests }\end{array}$ & $116(348)$ & $4(8)$ & $0(0)$ & 356 & 2.96 & 98.66 & III \\
\hline 20. & Damaged by Blue bull & $114(342)$ & $4(8)$ & $2(2)$ & 352 & 2.93 & 97.66 & VI \\
\hline 21. & Gram is sensitive to lightening & $76(228)$ & $23(46)$ & $21(21)$ & 272 & 2.26 & 75.33 & XVI \\
\hline 22. & Poor extent of knowledge about seed treatment & $115(345)$ & $3(6)$ & $2(2)$ & 353 & 2.94 & 98.00 & V \\
\hline
\end{tabular}


Table.2 Relationship between farmers' independent variables and dissuading factors for not including chickpea in the cropping system

\begin{tabular}{|c|l|c|}
\hline Sr. No. & Variables & Correlation coefificient $(r)$ \\
\hline 1. & Age $\left(\mathrm{X}_{1}\right)$ & 0.040 \\
\hline 2. & Education $\left(\mathrm{X}_{2}\right)$ & $0.002 *$ \\
\hline 3. & Caste $\left(\mathrm{X}_{3}\right)$ & -0.074 \\
\hline 4. & Family type $\left(\mathrm{X}_{4}\right)$ & 0.033 \\
\hline 5. & Family size $\left(\mathrm{X}_{5}\right)$ & $-0.018 *$ \\
\hline 6. & Occupation $\left(\mathrm{X}_{6}\right)$ & $0.019 *$ \\
\hline 7. & Land holding $\left(\mathrm{X}_{7}\right)$ & 0.037 \\
\hline 8. & Farm implements $\left(\mathrm{X}_{8}\right)$ & 0.072 \\
\hline 9. & Mass media exposure $\left(\mathrm{X}_{9}\right)$ & -0.073 \\
\hline 10. & Extension contact $\left(\mathrm{X}_{10}\right)$ & -0.133 \\
\hline 11. & Irrigation facilities $\left(\mathrm{X}_{11}\right)$ & $\mathbf{0 . 1 2 6}$ \\
\hline
\end{tabular}

*Correlation is significant at the 0.05 level of significance

'Economic losses under storage conditions due to stored grain pests', 'high incidence of wilt and root rot', 'poor extent of knowledge about seed treatment', 'insect pest control and disease control management', 'damage by blue bull', 'unstable production due to biotic and abiotic stresses' and 'heavy infestation of Helicoverpa armigera' with 99.33 per cent, 98.66 per cent, 98.33 per cent, 98.00 per cent, 97.66 per cent, 97.33 per cent and 96.00 per cent ranked at $2^{\text {nd }}, 3^{\text {rd }}, 4^{\text {th }}, 5^{\text {th }}, 6^{\text {th }}, 7^{\text {th }}$ and $8^{\text {th }}$ respectively for not including chickpea in cropping system. Some other dissuading factors were 'sensitive to changing weather conditions', 'high infestation of termites', 'less awareness of varieties of chickpea', 'viral infestation in desi chana', 'heavy weed infestation', 'bio-fertilizers are very costly', 'sensitive to high rainfall', 'sensitive to lightening', 'lack of infrastructural facilities for storage', 'low response to higher application of farm inputs', 'lack of inputs, low yield in tube well irrigated area', 'high cost of seed at the time of sowing' and 'can't grow in heavy soil' with 95 per cent, 93.33 percent, 92.66 per cent, 91.66 per cent, 87 per cent, 86.33 per cent, 83.33 per cent, 75.33 per cent, 71.66 per cent, 59.33 per cent, 51.66 per cent, 51 per cent, 43 per cent and 35 per cent ranked at $9^{\text {th }}, 10^{\text {th }}, 11^{\text {th }}, 12^{\text {th }}, 13^{\text {th }}, 14^{\text {th }}, 15^{\text {th }}$, $16^{\text {th }}, \quad 17^{\text {th }}, 18^{\text {th }}, \quad 19^{\text {th }}, 20^{\text {th }}, \quad 21^{\text {st }}, 22^{\text {nd }}$, respectively. The similar result found by Bhatia (1991) who reported low yield potential of chickpea due to low level of technological gap and susceptibility to pests and diseases. Table 2 indicates that education of the farmers $(r=0.002)$ was positively and significantly correlated at 1.00 percent level of significance with dissuading factor, family size $(r=-0.018)$ is negatively and significantly correlated with dissuading factors and occupation of the farmers (0.019) was positively and significantly correlated with dissuading factors.

This clearly shows that if education of farmers were high then farmers dissuade to include chickpea in cropping system and viceversa. If family size is small, farmers dissuade to include chickpea in cropping system. If occupation of respondents is other than agriculture, farmers dissuade to include chickpea in cropping system.

Regarding dissuading factors for not including chickpea in cropping system, it was 
found that 'low yield potential of chickpea' was most accountable factor followed by 'lack of promising varieties particularly for irrigated and drought prone areas', 'economic losses under storage conditions due to stored grain pests', 'high incidence of wilt and root rot', 'poor extent of knowledge about seed treatment', 'insect-pest control and disease control management', 'damage by blue bulls', 'unstable production due to biotic and abiotic stress', 'sensitive to changing weather conditions'. While 'infestation of termites', 'less awareness about new varieties', 'viral infestation in desi chana', 'heavy weed infestation', 'high cost of seed at the time of sowing', 'low yield in tube well irrigated area' were least accountable dissuading factors felt by the respondents.

\section{References}

Bhatia, M. S. (1991). Economic constraints in Increasing pulses production.
Agricultural Situation in India. 46 (4): 279-284.

Singh S., Jain S., Satyapriya and Dutt T. (2015). Constraints analysis in chickpea cultivation in disadvantaged region of Bundelkhand. Indian Research Journal of Extension Education.15 (4). 128-131.

Soni SN. (2002). Perception analysis of adoption of improved gram production technologies. Maharashtra J Extension Education. 3 (4\&5): 62-65.

Thoke. N and Gunjal. S. (2009). Constraints and suggestions of chickpea growers in adoption of its technology. Hind Agriciulture Research and Training Institute.4 (3\&4): 411-413.

Umrathaiya K., Choudhary. S. and Swarnakar V.K. (2015). Comparative study on adoption of improved chickpea varieties in Indore district of M.P. Iosr Journal of Agriculture and Veternary Science 8(8): $1-8$.

\section{How to cite this article:}

Nidhi Sharma, Aditya and Shehrawat, P.S. 2018. A Study of Factors Dissuading the Farmers to Include Chickpea in their Cropping System. Int.J.Curr.Microbiol.App.Sci. 7(05): 1800-1804. doi: https://doi.org/10.20546/ijcmas.2018.705.211 